Pak. j. sci. ind. res. Ser. B: biol. sci. 2018 61B(1) 32-46

\title{
Bioactivity Studies on Two Wild Edible Mushrooms Extracts
}

\author{
Funmilayo Bosede Borokini*a ${ }^{*}$ Mary Tolulope Olaleye ${ }^{b}$ and Labunmi Lajide \\ ${ }^{a}$ Department of Chemistry, University of Medical Science, Laje, Ondo City - 0340001, Ondo State, Nigeria \\ ${ }^{b}$ Department of Biochemistry, Federal University of Technology, Akure, PMB 704, Akure, Ondo State, Nigeria \\ ${ }^{c}$ Department of Chemistry, Federal University of Technology, Akure, PMB 704, Akure, Ondo State, Nigeria
}

(received August 20, 2015; revised January 5, 2017; accepted January 11, 2017)

\begin{abstract}
The aqueous and alcoholic extracts of Lentinus squarrosulus and Termitomyces robustus were analysed for phytochemicals, antioxidant and antimicrobial activities. Polyphenolic profile of the ethanol extracts revealed the presence of phenolic acids and flavonoids at different concentrations. Total phenol and total flavonoid contents demonstrated concentration dependent increase and positive correlation with the antioxidant activities in the corresponding extracts in the range of TFC $(r=0.794-0.993 ; 0.904-1.000)$ and TPC ( $\mathrm{r}=0.317-0.999 ; 0.621-0.995)$ for $L$. squarrosulus and T. robustus extracts, respectively. Inhibition concentrations at $50 \%\left(\mathrm{IC}_{50}\right)$ for each extract in terms of its reducing and scavenging ability ranged from 0.54 to $15.04 \mathrm{mg} / \mathrm{mL}$ for total antioxidant property (TAP), ferric reducing antioxidant property (FRAP), $\mathrm{DPPH}, \mathrm{OH}$ and NO radicals. Mushrooms extracts exhibited significant antifungal activities against Aspergillus fumigatus and Candida albican compared to bonlate but weak antibacterial activities against Bacillus substilis, Escherichia coli and Salmonella typhi compared to streptomycin sulphate. The mushrooms possessed appreciable antioxidant and antifungal properties for promoting good health.
\end{abstract}

Keywords: phytochemicals, antioxidant, antimicrobial activity, mushrooms

\section{Introduction}

Antioxidants play an important role in maintaining human health due to their ability to scavenge free radicals in the bodies. Reactive free radicals either from endogenous sources, through normal physiological and metabolic processes or exogenous sources by exposure to pollutants are harmful and capable of oxidizing biomolecules, resulting in cell death and tissue damage (Barros et al., 2008; Ames et al., 1993). Flavonoids and other phenolic compounds of plant origin are nonenzymatic antioxidants that have been reported as scavengers of free radicals (Rice-Evans et al., 1997). Coumarin is useful in pharmaceutical for its physiological, bacteriostatic and anti-tumor activity, though its hepatotoxicity in animal models has been reported (Jain and Himanshu, 2012). Flavonoids and coumarin exhibit a common benzopyrone structure and have been reported to possess various beneficial properties (Cook and Samman, 1996). The place of natural antioxidants in form of food nutrients or phytochemicals from plant origin cannot be underestimated in maintaining human health due to their ability to scavenge free radicals in the body; thereby supplementing the defense mechanisms of antioxidant enzymes such as superoxide dismutase, glutathione and catalase to fight harmful substances and prevent cell damages (Halliwell, 1996). Phytochemicals

*Author for correspondence; E-mail: borokinif59@yahoo.com have been evinced as effective antioxidants that can help in the fight against the prevailing degenerative and chronic diseases.

Many researchers reported that mushrooms are rich sources of natural phytochemicals that can make them find different applications as functional foods and excellent sources of nutraceuticals (Abdullah et al., 2015; Obodai et al., 2014). Some have been reported to function as antioxidants and potential fermentation agents to enhance feed nutrition (Abdullah et al., 2015) and primordial and anthropogenic radio-nuclides composition study in some edible mushrooms samples in Nigeria revealed that the effective doses from selected primordial radionuclides were within acceptable limit (Faweya et al., 2015; IAEA, 1994) making them safe for consumption. Nevertheless, mushrooms are yet to take the proper place in human diet and nutrition as many varieties are yet to be exploited and are still in the wild despite having been used as food and medicine since ancient times. Phenolic compounds, protein hydrolyzates and some amino acids, present in different foods, were evinced to possess antioxidant properties (Yun-Zhong et al., 2002). Phenols are important plant constituents because of their scavenging ability due to their hydroxyl groups (Arbaayah and Umi, 2013). Studies have established that macro fungi like mushrooms as well as fruits and vegetables are very important 
in diets to offer adequate security. Some common edible mushrooms have currently been found to possess physiologically beneficial bioactive substances with antioxidant activity, which is well correlated with their total phenolic content (Barros et al., 2007) and can promote good health.

Antibiotic resistance has also become a global concern in recent years. Despite the huge diversity of natural and synthetic antimicrobial compounds that have been isolated or synthesized against pathogenic microorganisms, infectious diseases remain one of the major threats to human health and bacterial resistance to many antibiotics has been increasing. The increasing failure of chemotherapeutics and antibiotic resistance exhibited by pathogenic microorganisms has led to the screening of novel sources for the potential antibacterial and antifungal activity (Nedelkoska et al., 2013; Colombo and Bosisio, 1996). In search of novel therapeutic alternatives, natural resources have been exploited in the previous years and among them mushrooms could be an alternative source of new antimicrobials.

Many fungal and plant based studies have found compounds with various health promoting properties, ranging from anti-carcinogenic, anti-inflammatory, and immunosuppressive (Hearst et al., 2010; Rao et al., 2009), antimicrobial, antioxidant, antitumor, cholesterol lowering and immunostimulatory effects as reported by many researchers (Kosani et al., 2013; Barros et al., 2007). Due to their rich deposit of bioactive compounds (Yamac and Bilgili, 2006) in many species of mushrooms; they produce a wide range of secondary meta bolites with high therapeutic effect and contain minerals, vitamins (Priya and Srinivasan, 2013), especially B-complex, micronutrients such as selenium or chromium, $\beta$-glucans, lipids, proteins, and all essential amino acids as well as other organic acids (Iwalokun et al., 2007). Most of the mushrooms consumed in Nigeria are picked from the wild by rural dwellers when environmental conditions favour their sporocarp formation (Aremu et al., 2009) and sold at high price in local markets; there is no record of any significant cultivation. Obodai et al. (2014) reported that either wild or cultivated samples of mushrooms are excellent low caloric diets, nutritionally rich for improving quality of life.

Many studies on nutritional and minerals contents of different common species have been carried out (Jonathan et al., 2011) but little or no work has been published on the antioxidant and antimicrobial activities of many wild edible species in many parts of Nigeria.
Also there are several wild edible species of mushrooms which are yet to be exploited. The present work therefore, has been focussed at evaluating the phenolic compounds, antioxidant and antimicrobial activities of Termitomyces robustus and Lentinus squarrosulus which are two common edible wild mushrooms in the western part of Nigeria.

\section{Materials and Methods}

Preparations of materials. The two species Termitomyces robustus and Lentinus squarrosulus (Fig. 1-2) obtained from local markets in Nigeria, were scraped and thoroughly cleaned with water to remove sand (both the pileus and stipes), cut into smaller pieces, oven dried at $60{ }^{\circ} \mathrm{C}$, then ground and sieved to give $40 \mathrm{~mm}$

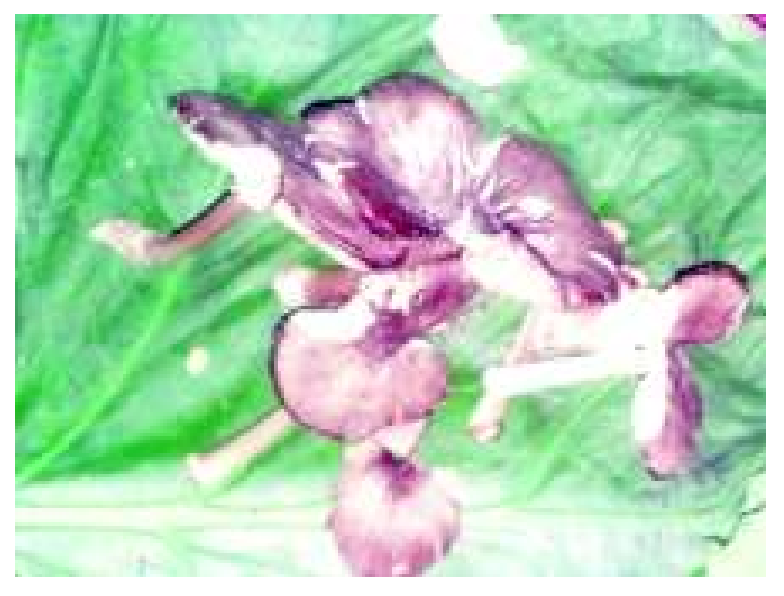

Fig. 1. T. robustus (Purchased at Koko market, Owo).

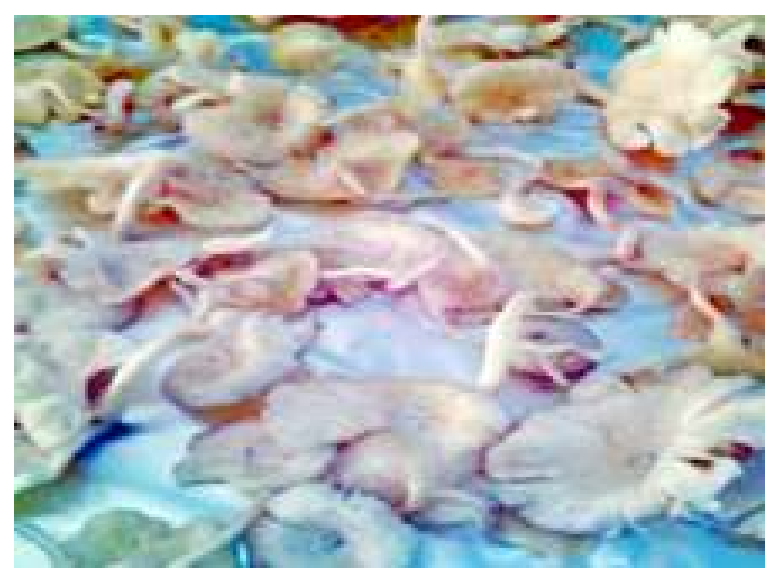

Fig. 2. L. squarrosulus (Purchased at Koko market, Owo). 
mesh size powder. The microorganisms (bacterial; Bacillus subtilis, Escherichia coli and Salmonella typhi and fungi; Aspergillus fumigatus, Fusarium solani and Candida albican were obtained from Federal University of Technology, Akure in Ondo State, Nigeria, identified and subsequently maintained as stock strains. Simple susceptibility screening test using agar well diffusion method was employed and each microorganism was suspended in sterile saline and diluted to $10^{-6}$ colony forming unit (CFU).

Preparation of bioactive extracts. Bioactive extracts of each powdered mushroom were obtained by weighing $20 \mathrm{~g}$ into cleaned and dried reagent bottle and $400 \mathrm{~mL}$ each of distilled water, methanol and ethanol were separately added and subjected to cold maceration process for $24 \mathrm{~h}$ to obtain the aqueous extract and $72 \mathrm{~h}$ to obtain the alcohol extracts. The mixtures were filtered using cheese cloth and then through Whatman No.1 filter paper. The filtrates were then concentrated using rotary evaporator and freeze drier (Iweala and Okeke, 2005).

Determination of antibacterial activity. The antibacterial activity of aqueous, methanolic and ethanolic extracts of the mushrooms against B. subtilis, E. coli and $S$. typhi bacteria was evaluated by using agar well diffusion method (Srinivasan et al., 2001). Plate count agar (PCA) plates were inoculated with $100 \mu \mathrm{L}$ of standardized inoculum $\left(1.5 \times 10^{8} \mathrm{CFU} / \mathrm{mL}\right)$ of each selected bacterium and spread with sterile swabs. Wells of $8 \mathrm{~mm}$ size diameter were made with sterile borer into agar plates containing the bacterial inoculum and the lower portion was sealed with a little molten agar medium. About $0.5 \mathrm{~mL}$ volume of each of the extracts was poured into a well of inoculated plates. Streptomycin sulphate $(10 \mu \mathrm{g} / \mathrm{mL})$ was used as a positive control which was introduced into a well instead of extract. The solvents; deionized water, methanol or ethanol were used as a negative control which was introduced into a well instead of the extracts. The plates thus prepared were left at room temperature for $10 \mathrm{~min}$ allowing the diffusion of the extract into the agar. After incubation for $24 \mathrm{~h}$ at $37^{\circ} \mathrm{C}$, the plates were observed. If antibacterial activity was present on the plates, the zone of inhibition was measured and expressed in $\mathrm{mm}$.

Determination of antifungal activity. The antifungal activity of mushroom extracts was evaluated against food associated fungi by using poisoned food technique. Potato dextrose agar (PDA), was weighed ( $39 \mathrm{~g}$ ) and dispersed in a litre of deionised water sterilized at $121{ }^{\circ} \mathrm{C}$ for $15 \mathrm{~min}$, allowed to cool $\left(45^{\circ} \mathrm{C}\right)$ before pouring $20 \mathrm{~mL}$ into separated dishes. The fungi; Aspergillus fumigatus, Fusarium solani and Candida albican were inoculated on potato dextrose agar (PDA) plates and incubated for $25^{\circ} \mathrm{C}$ for $72 \mathrm{~h}$, to obtain young actively growing colonies of moulds and $0.2 \mathrm{~mL}$ of each of the extract was mixed with $20 \mathrm{~mL}$ of cooled $\left(45^{\circ} \mathrm{C}\right)$ molten PDA medium and allowed to solidify at room temperature for $30 \mathrm{~min}$. Thereafter $10 \mu \mathrm{L}$ of fungal spores in distilled water was added at the centre of the solidified PDA plates. PDA plates with $10 \mu \mathrm{g} / \mathrm{mL}$ of bonlate were used as positive control. PDA plates with the solvents; deionized water, methanol or ethanol were used as negative control (McCutcheon et al., 1994). The inoculated plates were incubated at $25^{\circ} \mathrm{C}$ and colony mean diameter was measured and recorded after 3 days. Percentage mycelial growth inhibition (\% MGI) was calculated as given below:

$\% \mathrm{MGI}=\frac{\begin{array}{l}\text { Diameter of fungal colony in control- } \\ \text { diameter of fungal colony in extract }\end{array}}{\text { diameter of fungal colony in control }} \times 100$

Quantification of phenolic compounds in ethanolic extracts by HPLC-DAD. Chromatographic analyses were carried out under gradient conditions using $\mathrm{C}_{18}$ column $(4.6 \mathrm{~mm} \times 250 \mathrm{~mm})$ in reverse phase, packed with $5 \mu \mathrm{m}$ diameter particles. The mobile phase was water containing $1 \%$ acetic acid (A) and methanol (B), and the composition gradient was: $5 \%$ of $\mathrm{B}$ until 10 min and changed to obtain 20,30, 50, 60, 70, 20 and $10 \% \mathrm{~B}$ at $20,30,40,50,60,70$ and $80 \mathrm{~min}$, respectively, following the method described by Silva et al. (2014) with slight modifications. L. squarrosulus and T. robustus extracts and mobile phase were filtered through 0.45 $\mu \mathrm{m}$ membrane filter (Millipore) and then degassed by ultrasonic bath prior to use, L. squarrosulus and $T$. robustus extracts were analysed at a concentration of $15 \mathrm{mg} / \mathrm{mL}$. The flow rate was $0.6 \mathrm{~mL} / \mathrm{min}$, injection volume $50 \mu \mathrm{L}$ and the wavelength were 270 for gallic acid, $278 \mathrm{~nm}$ for coumarin, $327 \mathrm{~nm}$ for chlorogenic acid and caffeic acid, and $365 \mathrm{~nm}$ for quercetin, quercitrin, kaempferol and rutin. Stock solutions of standards references were prepared in the high-performance liquid chromatography (HPLC) mobile phase at a concentration range of $0.025-0.250 \mathrm{mg} / \mathrm{mL}$ for quercetin, quercitrin, kaempferol, coumarin and rutin; and $0.030-0.300 \mathrm{mg} / \mathrm{mL}$ for gallic, caffeic and chlorogenic acids. Chromatography peaks were confirmed by comparing its retention time 
with those of reference standards and by DAD spectra (200-500 nm). Calibration curve for gallic acid: $\mathrm{Y}=$ $13480 \mathrm{x}+1257.5(\mathrm{r}=0.9998)$; coumarin: $\mathrm{Y}=11983 \mathrm{x}$ $+1196.9(\mathrm{r}=0.9997)$; chlorogenic acid: $\mathrm{Y}=11786 \mathrm{x}+$ $1267.1(\mathrm{r}=0.9991)$; caffeic acid: $\mathrm{Y}=13048 \mathrm{x}+1345.6$ $(\mathrm{r}=0.9995)$; rutin: $\mathrm{Y}=12478 \mathrm{x}+1194.9(\mathrm{r}=0.9997)$, quercitrin: $\mathrm{Y}=13641 \mathrm{x}+1178.4(\mathrm{r}=0.9997)$, kaempferol: $\mathrm{Y}=11458 \mathrm{x}+1269.4(\mathrm{r}=0.9998)$ and quercetin: $\mathrm{Y}$ $=12783 \mathrm{x}+1195.8(\mathrm{r}=0.9996)$. All chromatography operations were carried out at ambient temperature and in triplicate. The limit of detection (LOD) and limit of quantification (LOQ) were calculated based on the standard deviation of the responses and the slope using three independent analytical curves. LOD and LOQ were calculated as 3.3 and $10 \sigma / \mathrm{S}$, respectively, where $\sigma$ is the standard deviation of the response and $\mathrm{S}$ is the slope of the calibration curve (Silva et al., 2014).

Determination of total phenol contents. The total phenol content (TPC) of the samples was determined by mixing $0.5 \mathrm{~mL}$ of each extract with $2.5 \mathrm{~mL} 10 \%$ Folin-Cioalteu's reagent (v/v) and $2.0 \mathrm{~mL}$ of $7.5 \%$ $\mathrm{Na}_{2} \mathrm{CO}_{3}$. The reaction mixture was subsequently incubated at $45^{\circ} \mathrm{C}$ for $40 \mathrm{~min}$, and the absorbance measured at $760 \mathrm{~nm}$ in the spectrophotometer. All tests were performed three times. Gallic acid was used as a standard phenolic compound. The amount of total phenolic compound in the extract was determined as $\mu \mathrm{g}$ of gallic acid equivalent (GAE) per g dry weight (Singleton et al., 1999).

Determination of total flavonoid. The flavonoid content (TFC) of the extract was determined using a colorimetric assay developed by Zhishen et al. (1999). A known volume $(0.5 \mathrm{~mL})$ of each extract was added to a $10 \mathrm{~mL}$ volumetric flask. Distilled water was added to make a volume of $5 \mathrm{~mL}$. At zero time, $0.3 \mathrm{~mL}$ of $5 \% \mathrm{w} / \mathrm{v} \mathrm{NaNO}$ was added to the flask. After $5 \mathrm{~min}, 0.6 \mathrm{~mL}$ of $10 \% \mathrm{w} / \mathrm{v}$ $\mathrm{AlCl}_{3}$ was added and after $6 \mathrm{~min}, 2 \mathrm{~mL}$ of $1 \mathrm{M} \mathrm{NaOH}$ was added to the mixture followed by the addition of $2.1 \mathrm{~mL}$ distilled water. Absorbance was read at $510 \mathrm{~nm}$ against the blank (water) and flavonoid content expressed as $\mathrm{mg}$ rutin equivalent $/ \mathrm{g}$.

Determination of 2, 2-Diphenyl-1-picryl hydrazyl (DPPH) radical scavenging ability. The free radical scavenging ability of the extract against DPPH free radical was evaluated by Ursini et al. (1994). Extracts of $1-5 \mathrm{mg} / \mathrm{mL}$ each was mixed with $1 \mathrm{~mL}, 0.4 \mathrm{mM}$ methanolic solution containing DPPH radicals, the mixture was left in the dark for $30 \mathrm{~min}$ before measuring the absorbance at $516 \mathrm{~nm}$.

$$
\% \text { of Inhibition }=\frac{\text { Ao-A } 1}{\text { Ao }} \times 100
$$

where:

Ao $=$ absorbance of the trolox and A1 $=$ absorbance of the sample.

Determination of $\mathrm{OH}$ radical scavenging activity. Exactly $1-5 \mathrm{mg} / \mathrm{mL}$ of each extract of the samples were mixed with $1 \mathrm{~mL}$ of reaction mixture $\left(100 \mu \mathrm{M} \mathrm{FeCl}_{3}\right.$, $104 \mu \mathrm{M}$ ethylenediamine tetra acetic acid, $1.5 \mathrm{M} \mathrm{H}_{2} \mathrm{O}_{2}$, $2.5 \mathrm{M}$ deoxyribose and $100 \mu \mathrm{M}$ ascorbic acid in $10 \mathrm{mM}$ $\mathrm{KH}_{2} \mathrm{PO}_{4}-\mathrm{KOH}, \mathrm{pH} 7.4$ ) and incubated for $1 \mathrm{~h}$ at $37{ }^{\circ} \mathrm{C}$. Thereafter, $1 \mathrm{~mL}$ of $0.5 \%$ thiobarbituric acid in 0.025 $\mathrm{M} \mathrm{NaOH}$ and $1 \mathrm{~mL}$ of $2.8 \%$ trichloroacetic acid was added to the mixture and heated for $30 \mathrm{~min}$ at $80^{\circ} \mathrm{C}$ before reading the absorbance at $532 \mathrm{~nm}$ against an appropriate blank solution (Heo and Lim, 2004). All tests were performed three times. Ascorbic acid was used as a positive control. Percent inhibition of $\mathrm{OH}$ was calculated by the following expression:

$$
\% \text { of Inhibition }=\frac{\text { Ao-A } 1}{\text { Ao }} \times 100
$$

where:

$\mathrm{Ao}=$ absorbance of the ascorbic acid and $\mathrm{A} 1=$ absorbance of the sample.

Determination of NO scavenging activity. Briefly, $5 \mathrm{mM}$ sodium nitroprusside in phosphate-saline was mixed with different concentrations of the extracts: $1-5 \mathrm{mg} / \mathrm{mL}$, before incubation at $25{ }^{\circ} \mathrm{C}$ for $150 \mathrm{~min}$. Thereafter, the reaction mixture was added to Greiss reagent ( $1 \%$ sulfanilamide, $2 \% \mathrm{H}_{3} \mathrm{PO}_{4}$ and $0.1 \%$ naphthylethylenediamine dihydrochloride), before measuring the absorbance at $546 \mathrm{~nm}$ (Jagetia et al., 2004). Ascorbic acid was used as control. The nitric oxide radicals scavenging activity of the fractions was calculated according to the following equation:

$$
\% \text { of Inhibition }=\frac{\text { Ao-A } 1}{\text { Ao }} \times 100
$$

where:

Ao $=$ absorbance of ascorbic acid and A1 $=$ absorbance in the presence of the fractions and ascorbic acid.

Determination of ferric reducing antioxidant property (FRAP). The reducing property of the extract was 
determined by assessing the ability of the extracts to reduce $\mathrm{FeCl}_{3}$ solution as described by Pulido et al. (2000). Each of the extracts $(1-5 \mathrm{mg} / \mathrm{mL})$ was mixed with $2.5 \mathrm{~mL}, 200 \mathrm{mM}$ sodium phosphate buffer $(\mathrm{pH}$ 6.6) and $2.5 \mathrm{~mL}$ of $1 \%$ potassium hexacyanoferrate (III) $\left(-\mathrm{K}_{3}\left[\mathrm{Fe}(\mathrm{CN})_{6}\right]\right)$. The mixture was incubated at $50{ }^{\circ} \mathrm{C}$ for $20 \mathrm{~min}$, thereafter $2.5 \mathrm{~mL}, 10 \%$ trichloroacetic acid was also added and subsequently centrifuged at 650 rpm for $10 \mathrm{~min}, 5 \mathrm{~mL}$ of the supernatant was then mixed with equal volume of water and $1 \mathrm{~mL}$ of $0.1 \% \mathrm{FeCl}_{3}$. The absorbance was measured at $700 \mathrm{~nm}$, the higher the absorbance, the higher the reducing power.

Determination of total antioxidant activity (TAP). The assay is based on the reduction of Mo (VI)-Mo (V) by the extracts and the subsequent formation of a green phosphate/Mo (V) complex at acidic $\mathrm{pH}$ as described by Prieto et al. (1999). Exactly $0.2 \mathrm{~mL}$ of the different extracts $(1-5 \mathrm{mg} / \mathrm{mL})$ was combined with $3 \mathrm{~mL}$ of each reagent solution $\left(0.6 \mathrm{M} \mathrm{H}_{2} \mathrm{SO}_{4}, 28 \mathrm{mM} \mathrm{Na}_{3} \mathrm{PO}_{4}\right.$ and 4 $\left.\mathrm{mM}\left(\mathrm{NH}_{4}\right)_{2} \mathrm{MoO}_{4}\right)$. The tubes were incubated at $95{ }^{\circ} \mathrm{C}$ for $90 \mathrm{~min}$ and the absorbance measured at $695 \mathrm{~nm}$ against the blank after the mixtures have cooled to room temperature. The antioxidant activity was expressed as gallic acid equivalent.

Statistical analysis. Values are presented as the mean \pm SD of three replicates. ANOVA and LSD and Pearson correlation analyses were performed using the commercial software SPSS 16.0.

\section{Results and Discussion}

Phenolic compounds. Investigation of polyphenolic profile of ethanol extracts of Lentinus squarrosulus and Termitomyces robustus showed the presence of phenolic acids, flavonoids and coumarin (Table 1) which have been proofed through researches to possess various antioxidant properties. Flavonoids content was found to be higher in concentration than phenolic acids as indicated by the ratio of flavonoid to phenolic acids of 1.29 and 5.12 for L. squarrosulus and T. robustus, respectively in this study.

HPLC fingerprinting of extracts revealed the presence of the gallic acid $\left(t_{R}=11.67\right.$ min; peak 1$)$, chlorogenic acid $\left(t_{R}=21.45\right.$ min; peak 2$)$, caffeic acid $\left(t_{R}=24.08\right.$ min; peak 3$)$, coumarin $\left(t_{R}=30.21\right.$; peak 4$)$, rutin $\left(t_{R}\right.$ $=38.19 \mathrm{~min}$; peak 5), quercitrin $\left(t_{R}=46.57 \mathrm{~min}\right.$; peak $6)$, quercetin $\left(t_{R}=49.97\right.$ min; peak 7$)$ and kaempferol $\left(t_{R}=52.11\right.$ min; peak 8) (Fig. 3-4, Table 1). The limit of detection (LOD) and limit of quantification (LOQ) for the standards curves were: gallic acid $(\mathrm{LOD}=0.015$ and $\mathrm{LOQ}=0.049 \mathrm{~g} / \mathrm{mL}$ ), chlorogenic acid (LOD = 0.008 and $\mathrm{LOQ}=0.027 \mathrm{~g} / \mathrm{mL})$, caffeic acid $(\mathrm{LOD}=$ 0.023 and $\mathrm{LOQ}=0.076 \mathrm{~g} / \mathrm{mL})$, coumarin $(\mathrm{LOD}=0.021$ and $\mathrm{LOQ}=0.065 \mathrm{~g} / \mathrm{mL}$ ), rutin ( $\mathrm{LOD}=0.009$ and $\mathrm{LOQ}$ $=0.031 \mathrm{~g} / \mathrm{mL})$, quercitrin $(\mathrm{LOD}=0.027$ and LOQ $=$ $0.089 \mathrm{~g} / \mathrm{mL})$, quercetin $(\mathrm{LOD}=0.011$ and $\mathrm{LOQ}=0.037$ $\mathrm{g} / \mathrm{mL}$ ) and kaempferol $(\mathrm{LOD}=0.030$ and $\mathrm{LOQ}=0.098$ $\mathrm{g} / \mathrm{mL})$.

Table 1. Phenolic profile of ethanol extracts of mushrooms

\begin{tabular}{llc}
\hline \hline Compounds & L. squarrosulus & T. robustus \\
\cline { 2 - 3 } & \multicolumn{2}{c}{$(\mathrm{mg} / \mathrm{g})$} \\
\hline Gallic acid & $0.93^{\mathrm{a}} \pm 0.01$ & $1.02^{\mathrm{a}} \pm 0.03$ \\
Chlorogenic acid & $1.15^{\mathrm{a}} \pm 0.01$ & $1.49^{\mathrm{b}} \pm 0.01$ \\
Caffeic acid & $9.87^{\mathrm{b}} \pm 0.03$ & $0.53^{\mathrm{c}} \pm 0.01$ \\
Coumarin & $7.04^{\mathrm{c}} \pm 0.02$ & $3.37^{\mathrm{d}} \pm 0.02$ \\
Rutin & $0.61^{\mathrm{d}} \pm 0.01$ & $1.38^{\mathrm{a}} \pm 0.01$ \\
Quercitrin & $3.52^{\mathrm{d}} \pm 0.02$ & $6.12^{\mathrm{e}} \pm 0.01$ \\
Quercetin & $4.11^{\mathrm{f}} \pm 0.03$ & $3.80^{\mathrm{d}} \pm 0.03$ \\
Kaempferol & $7.19^{\mathrm{c}} \pm 0.02$ & $4.25^{\mathrm{f}} \pm 0.01$ \\
\hline \hline
\end{tabular}

Values represent means of triplicate readings \pm S.D. Values with the same superscript along the row are not significantly different $(\mathrm{p}=0.05)$.

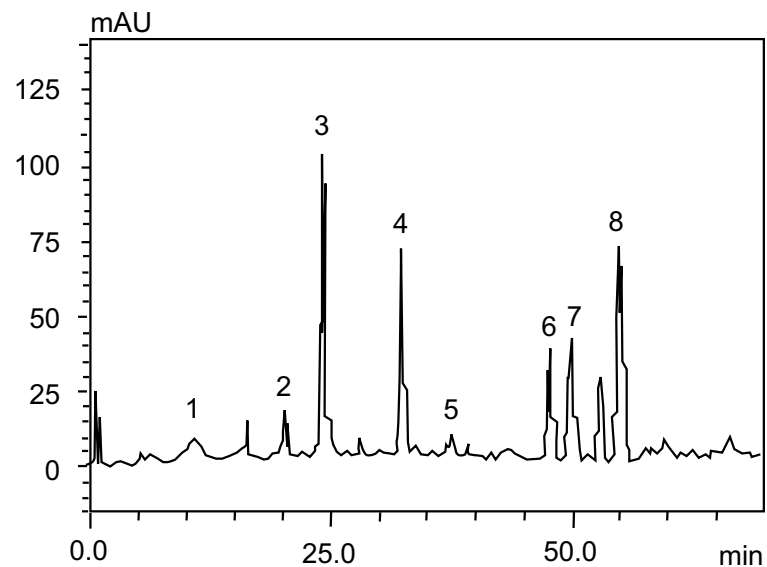

Fig. 3. Reverse-phase high performance liquid chromatography with Diode-Array Detection (HPLC-DAD) profile of Lentinus squarrosulus ethanol extract. Gallic acid (peak 1), chlorogenic acid (peak 2), caffeic acid (peak 3), coumarin (peak 4), rutin (peak 5), quercitrin (peak 6), quercetin (peak 7) and kaempferol (peak 8). 


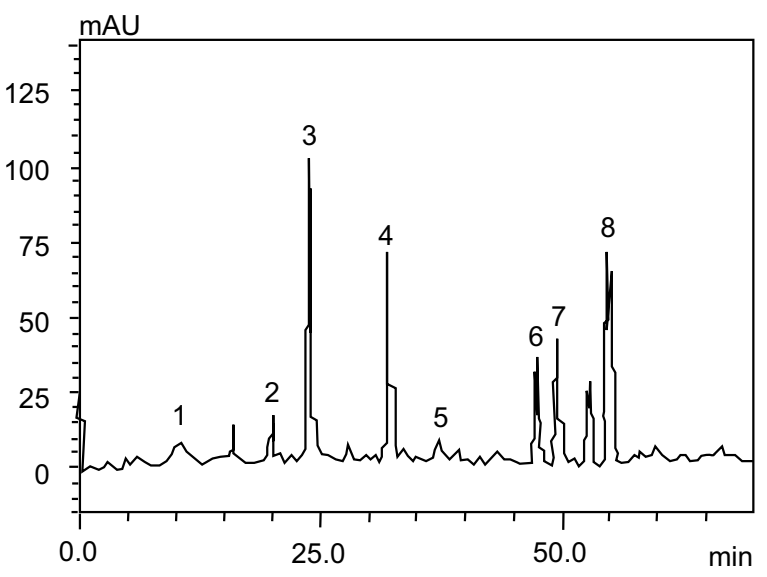

Fig. 4. HPLC-DAD profile of Termitomyces robustus ethanol extract.. Gallic acid (peak 1), chlorogenic acid (peak 2), caffeic acid (peak 3), coumarin (peak 4), rutin (peak 5), quercitrin (peak 6), quercetin (peak 7) and kaempferol (peak 8).

Total phenol and total flavonoid contents of mushrooms. Total phenol contents (TPC) are reported in $\mathrm{mg} / \mathrm{g}$ of DW as gallic acid equivalents by reference to standard curve $\left(\mathrm{y}=2.327, \mathrm{r}^{2}=0.9849\right)$ and total flavonoid contents (TFC) as rutin equivalent in $\mathrm{mg} / \mathrm{g}$ by reference to standard curve $\left(\mathrm{y}=8.250 \mathrm{x}, \mathrm{r}^{2}=0.998\right)$. For the aqueous and methanol extracts, $T$. robustus gave significantly higher values of total phenol $(\mathrm{p}=0.05)$ with the range $29.00 \pm 0.41$ to $61.60 \pm 0.33$ and $67.675 \pm 0.72$ to $259.96 \pm 1.21$, respectively than L. squarrosulus which range from $20.41 \pm 0.16$ to $55.859 \pm 0.11$ and $21.48 \pm$ 0.23 to $85.94 \pm 0.16$, but higher concentrations were observed in ethanol extracts of $L$. squarrosulus ; 22.344 \pm 0.31 to $107.421 \pm 0.28$ than $T$. robustus $16.76 \pm 0.28$ to $74.34 \pm 0.31$. The gallic acid used as the standard gave significantly higher values; $275.97 \pm 0.63$ to $1655.06 \pm 3.42$ than both mushrooms. Higher flavonoid contents were obtained in all the extracts of T. robustus $(54.55 \pm 0.09$ to $248.4848 \pm 0.72 ; 4.85 \pm 0.51$ to 31.45 \pm 0.44 ; and $0.97 \pm 0.03$ to $4.97 \pm 0.11)$ than L. squarrosulus (60.61 \pm 1.01 to $245.4545 \pm 2.34 ; 2.42 \pm 0.04$ to $13.23 \pm 0.16$ and $0.36 \pm 0.02$ to $2.97 \pm 0.04$ ), respectively except at lower concentrations of the aqueous extract. TFC of rutin ranged from $34.85 \pm 0.83$ to 181.82 \pm 0.89 . The variance observed in the extractive abilities of the solvents used in this study for TFC and TPC could be due to the fact that phenolic compounds in the fungi belong to different classes of phenols, which are selectively soluble in different solvents (Prior and Cao,
1999) and are associated with other non-phenolic molecules. Extraction of phenolic compounds is influenced by their chemical nature, extraction method, sample size, time and storage conditions as well as the presence of interfering substances. Aqueous extracts gave highest total phenol contents, followed by methanol. Polarity seems to be the major influence, though inconsistent with the trend observed for TFC. Antiseptic and anti-inflammatory functions of phenols in mushrooms are documented. The total phenolic concentration of the wild mushrooms (wild champignon: (Champignon) Agaricus sp., Boletus sp., and Macrolepiota sp.) was found to be in the range of 4.87 to $13.74 \mathrm{mg} \mathrm{CAE} / \mathrm{g}$ DW (Alvarez-Parrilla et al., 2007). Total flavonoid contents in the mushrooms extract varied from 1.40 to $29.80 \mathrm{mg} \mathrm{QE} / \mathrm{g}$ of DW of extracts in the ethanolic extracts of oyster mushrooms (P. pulmonarius, P. ostreatus, $P$. djamor var. djamor and $P$. djamor var. roseus) and the split gill mushroom (Schizophyllum commune) (Arbaayah and Umi, 2013).

DPPH radical scavenging properties of the mushrooms extracts. All the extracts of the two mushrooms demonstrated H-donor activities (Fig. 5a-c). Higher DPPH radical scavenging activity was detected in alcohol extracts than the aqueous extracts, contrary to the trend lines for TFC. It however agreed with the trend obtained for total TPC with few exceptions. The scavenging ability seems to increase with decrease in polarity of the solvent but correlation between TFC and TPC with corresponding DPPH scavenging capacities were strong and positive (Tables 2-3). $\mathrm{IC}_{50}$ values which represented the concentration of extracts capable of inhibiting $50 \%$ of radical solution are presented in Table 4. The higher the scavenging ability of extract the lower the inhibition concentrations at $50 \%\left(\mathrm{IC}_{50}\right)$. The $\mathrm{IC}_{50}$ for DPPH free radicals by a macro fungi; S. commune ethanol extracts which was $2.75 \mathrm{mg} / \mathrm{mL}$ as reported by Arbaayah and Umi (2013) was less than the range $3.39-8.78 \mathrm{mg} / \mathrm{mL}$ as calculated from the equation of the graph in this study. The aqueous, methanol and ethanol extracts of T. robusts showed the higher scavenging ability than L. squarrosulus. The alcohol extracts especially showed strong effectiveness in inhibiting DPPH though less effective than trolox.

Scavenging properties of $\mathrm{OH}$ of the mushrooms extracts. Scavenging of $\mathrm{OH}$ activity was determined by measuring the inhibition of degradation of deoxyribose by the free radicals generated by the Fenton reaction (Umamaheswari and Chatterjee, 2000). Aqueous extracts 
Table 2. Pearson's correlation coefficient between total phenol content (TPC) and antioxidant assays

\begin{tabular}{|c|c|c|c|c|c|c|c|}
\hline \multirow[t]{2}{*}{ TPC } & \multirow[t]{2}{*}{ Samples } & & \multicolumn{5}{|c|}{ Pearson's correlation } \\
\hline & & & DPPH & $\mathrm{OH}$ & $\mathrm{NO}$ & FRAP & TAP \\
\hline \multirow[t]{4}{*}{ Aqueous } & r value & T. robustus & $0.925^{*}$ & $0.887^{*}$ & 0.621 & $0.958^{*}$ & $0.995^{* *}$ \\
\hline & $\mathrm{p}$ value & & 0.025 & 0.045 & 0.264 & 0.010 & 0.000 \\
\hline & r value & L. squarrosulus & $0.889^{*}$ & $0.996^{* *}$ & 0.844 & $0.977^{* *}$ & $0.972^{* *}$ \\
\hline & $\mathrm{p}$ value & & 0.043 & 0.000 & 0.072 & 0.004 & 0.006 \\
\hline \multirow[t]{4}{*}{ Methanol } & r value & T. robustus & $0.993^{* *}$ & $0.938^{*}$ & 0.817 & $0.977^{* *}$ & $0.952^{*}$ \\
\hline & $\mathrm{p}$ value & & 0.001 & 0.018 & 0.091 & 0.004 & 0.013 \\
\hline & r value & L. squarrosulus & $0.983^{* *}$ & $0.968^{* *}$ & 0.317 & $0.995^{* *}$ & 0.855 \\
\hline & $\mathrm{p}$ value & & 0.003 & 0.007 & 0.603 & 0.000 & 0.065 \\
\hline \multirow[t]{4}{*}{ Ethanol } & r value & T. robustus & $0.973^{* *}$ & $0.993^{* *}$ & $0.989^{* *}$ & $0.982^{* *}$ & $0.966^{* *}$ \\
\hline & $\mathrm{p}$ value & & 0.005 & 0.001 & 0.001 & 0.003 & 0.007 \\
\hline & r value & L. squarrosulus & $0.990^{* *}$ & $0.985^{* *}$ & $0.991^{* *}$ & $0.998^{* *}$ & $0.999^{* *}$ \\
\hline & $\mathrm{p}$ value & & 0.001 & 0.002 & 0.001 & 0.000 & 0.000 \\
\hline \multirow[t]{2}{*}{ Control } & r value & - & $0.985^{* *}$ & $0.983^{* *}$ & $0.965^{* *}$ & $0.991^{* *}$ & $0.992^{* *}$ \\
\hline & $\mathrm{p}$ value & & 0.002 & 0.003 & 0.008 & 0.001 & 0.001 \\
\hline
\end{tabular}

FRAP $=$ ferric reducing antioxidant property; TAP $=$ total antioxidant property.

Table 3. Pearson's correlation coefficient between total flavonoid content and antioxidant assays

\begin{tabular}{|c|c|c|c|c|c|c|c|}
\hline \multirow[t]{2}{*}{ ТPC } & \multirow[t]{2}{*}{ Samples } & & \multicolumn{5}{|c|}{ Pearson's correlation } \\
\hline & & & $\mathrm{DPPH}$ & $\mathrm{OH}$ & NO & FRAP & TAP \\
\hline \multirow[t]{4}{*}{ Aqueous } & r value & T.robustus & $0.936^{*}$ & $0.973^{* *}$ & $0.904^{*}$ & $0.930^{*}$ & $0.915^{*}$ \\
\hline & $\mathrm{p}$ value & & 0.019 & 0.005 & 0.035 & 0.022 & 0.029 \\
\hline & r value & L.squarrosulus & $0.940^{*}$ & $0.985^{* *}$ & $0.926^{*}$ & $01.000^{* *}$ & $0.973^{* *}$ \\
\hline & $\mathrm{p}$ value & & 0.018 & 0.002 & 0.024 & 0.000 & 0.005 \\
\hline \multirow[t]{4}{*}{ Methanol } & r value & T.robustus & $0.968^{* *}$ & $0.994^{* *}$ & $0.919^{*}$ & $0.990^{* *}$ & $0.967^{* *}$ \\
\hline & $\mathrm{p}$ value & & 0.007 & 0.001 & 0.028 & 0.001 & 0.007 \\
\hline & r value & L.squarrosulus & $0.988^{* *}$ & $0.969^{* *}$ & 0.217 & $0.979^{* *}$ & 0.795 \\
\hline & $\mathrm{p}$ value & & 0.002 & 0.007 & 0.726 & 0.004 & 0.108 \\
\hline \multirow[t]{4}{*}{ Ethanol } & r value & T.robustus & $0.967^{* *}$ & $0.984^{* *}$ & $0.995^{* *}$ & $0.954^{*}$ & $0.983^{* *}$ \\
\hline & $\mathrm{p}$ value & & 0.007 & 0.002 & 0.000 & 0.012 & 0.003 \\
\hline & r value & L.squarrosulus & $0.988^{* *}$ & $0.975^{* *}$ & $0.988^{* *}$ & $0.999^{* *}$ & $0.993^{* *}$ \\
\hline & $\mathrm{p}$ value & & 0.002 & 0.005 & 0.002 & 0.000 & 0.001 \\
\hline \multirow[t]{2}{*}{ Control } & r value & - & $0.987^{* *}$ & $0.965^{* *}$ & $0.955^{*}$ & $0.968^{* *}$ & $0.988^{* *}$ \\
\hline & $\mathrm{p}$ value & & 0.002 & 0.008 & 0.011 & 0.007 & 0.002 \\
\hline
\end{tabular}

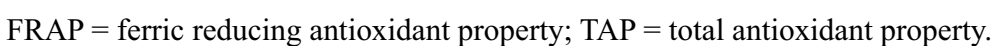

of both mushrooms strongly inhibited the production of hydroxyl radicals compared with the standard (ascorbic acid) (Fig. 6a). Aqueous extracts showed significantly higher scavenging abilities than the alcohol, and both mushrooms demonstrated increase in percentage inhibition with increasing extracts concentration (Fig. 6a-c) in agreement with the study on Aesculus indica leaves reported earlier (Guno, 2009) and had strong positive correlations with TFC and TPC (Tables 2-3). The least anti- OH property was observed in the methanol extracts of L. squarrosulus with $\mathrm{IC}_{50}$ value of $15.04 \mathrm{mg} / \mathrm{mL}$ calculated from the equation of the graph (Table 2).

Nitric oxide (NO) radical scavenging properties of the mushrooms extracts. Nitric oxide is important as a regulatory and signaling molecule, but it is also implicated in inflammation, cancer and other pathological conditions (Dharmendra et al., 2012) in addition to the reactive oxygen species. NO is known to be a ubiquitous free-radical moiety, which is distributed in tissues or organ systems and is supposed to have a vital 
role in neuromodulation or as a neurotransmitter in the CNS (Gulati et al., 2006), high levels of these radicals are toxic to tissue and contribute to the vascular collapse, various carcinoma and ulcerative colitis (Rajan et al., 2011). There was no regular trend observed in the scavenging ability for the extracts, except that aqueous and methanol extracts displayed significantly higher

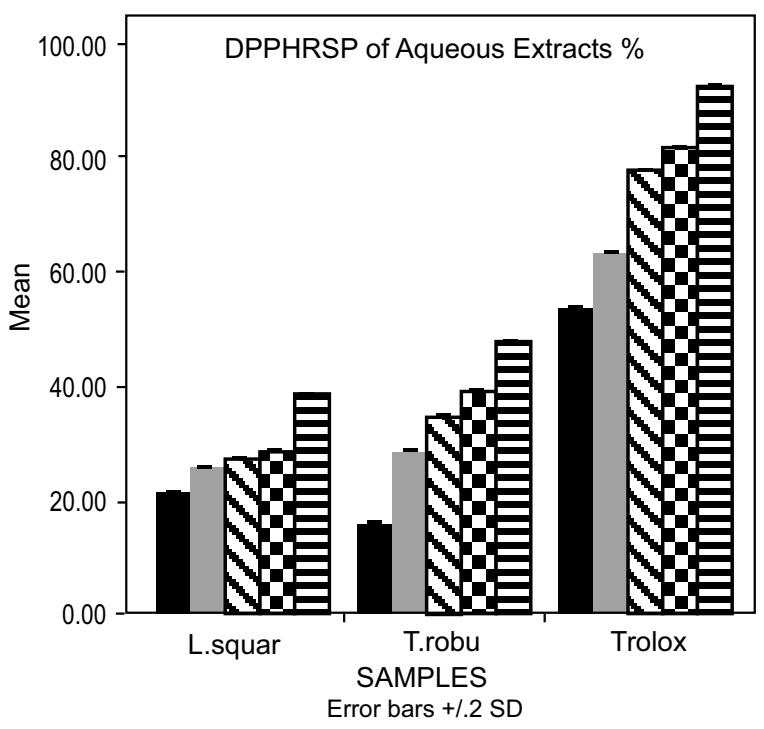

$1 \mathrm{mg} / \mathrm{mL} \square 2 \mathrm{mg} / \mathrm{mL} 3 \mathrm{mg} / \mathrm{mL}$ 皿 $4 \mathrm{mg} / \mathrm{mL}$ 曰 $5 \mathrm{mg} / \mathrm{mL}$

Fig. 5a. DPPH radical scavenging property in (aq).

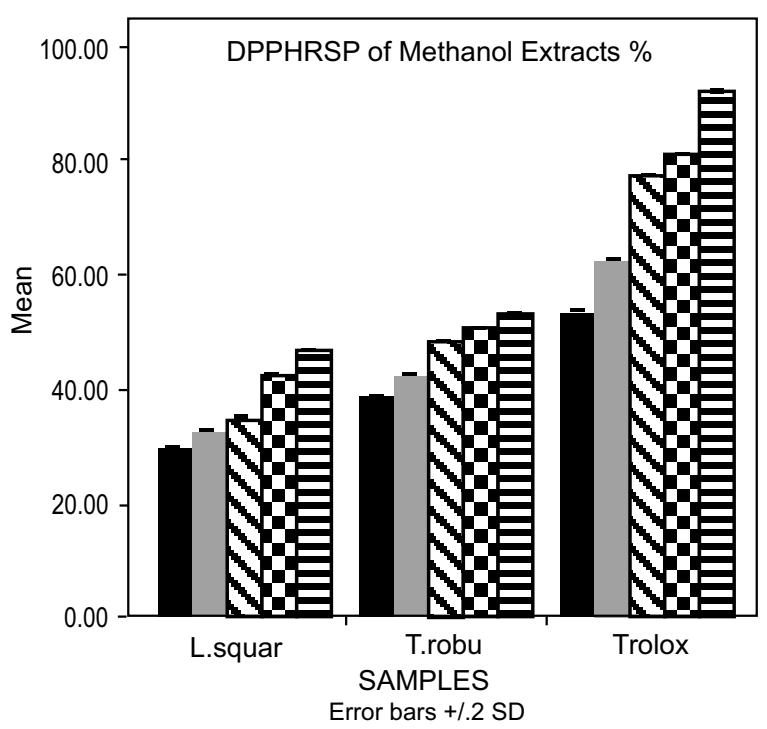

$1 \mathrm{mg} / \mathrm{mL} \square 2 \mathrm{mg} / \mathrm{mL} 3 \mathrm{mg} / \mathrm{mL}$ 四 $4 \mathrm{mg} / \mathrm{mL}$ 曰 $5 \mathrm{mg} / \mathrm{mL}$

Fig. 5b. DPPH radical scavenging property in $(\mathrm{MEOH})$. inhibition than the ethanol extracts (Fig. 7a-c). The least $\mathrm{IC}_{50}$ values was observed in methanol extract of T. robusts, an indication of more potency against NO (Table 4). The extracts of both mushrooms exhibited appreciable scavenging properties compared with ascorbic acid and there was a general positive correlation with TFC and TPC (Tables 2-3).

Ferric reducing antioxidant properties of the mushrooms extracts. The reductive capabilities of different extracts of the mushrooms increased with increasing concentrations of the extracts (Fig. 8a-c). The aqueous extracts of both mushrooms showed higher activity than the alcohol extracts but much lower than the ascorbic acid at all concentrations. The extracts acted as electron donor to reduce the ferricyanide $\left(\mathrm{Fe}^{3+}\right)$ to ferrocyanide $\left(\mathrm{Fe}^{2+}\right)$ (Arbaayah and Umi, 2013). The correlation of TFC and TPC with reducing capacities of corresponding extracts of T. robustus and L. squarrosulus were strongly positive (Tables 2-3). This agrees with the observation that the reducing power of a compound is known to be associated with the presence of certain antioxidant agents and reductones such as ascorbic acid (Jayaprakasha et al., 2007; Duh et al., 1999). The activities of mushrooms in this study compared favourably well with 62771.43 and $58528.57 \mu \mathrm{mol} / \mathrm{g}$ reported for methanol extracts of Boletus erythropus var. erythropus and Suillus luteus (Keleş et al., 2011), respectively.

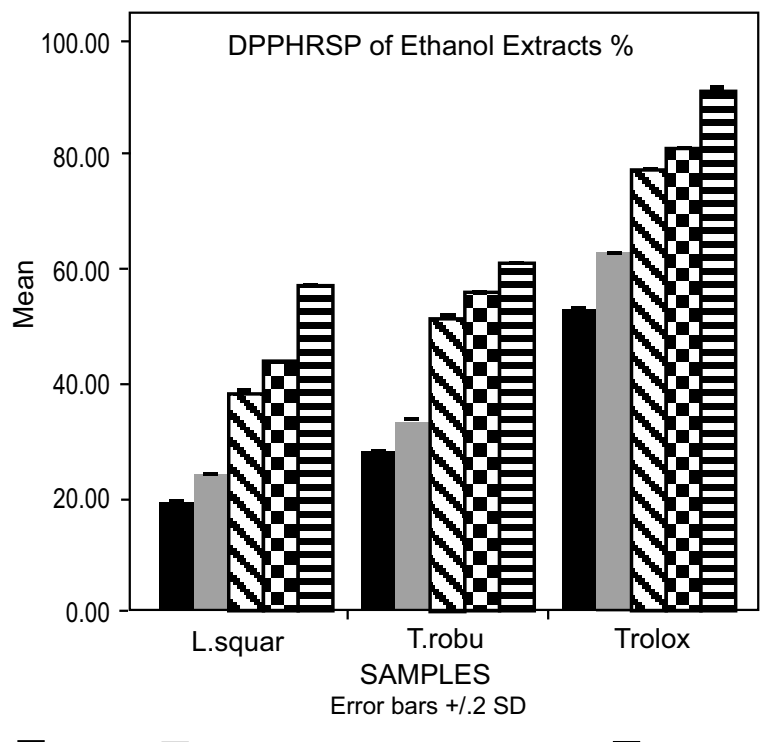

$1 \mathrm{mg} / \mathrm{mL} \square 2 \mathrm{mg} / \mathrm{mL} 3 \mathrm{mg} / \mathrm{mL} \mathbf{m g} / \mathrm{mL} \boxminus 5 \mathrm{mg} / \mathrm{mL}$

Fig. 5c. DPPH radical scavenging property in (ETOH). 
Table 4. $\mathrm{IC}_{50}$ values for $\mathrm{DPPH}, \mathrm{OH}$ and $\mathrm{NO}$ free radicals

\begin{tabular}{lllllll}
\hline \hline \multirow{2}{*}{ Solvents } & \multirow{2}{*}{ Samples } & \multicolumn{5}{c}{$\left(\mathrm{IC}_{50)}\right)$} \\
\cline { 3 - 7 } & & $\mathrm{DPPH}$ & $\mathrm{OH}$ & $\mathrm{NO}$ & FRAP & TAP \\
\hline \multirow{2}{*}{ Aqueous } & T. robustus & 5.27 & 0.54 & 4.61 & 1.28 & 1.18 \\
& L. squarrosulus & 8.78 & 1.76 & 4.72 & 1.62 & 1.58 \\
\multirow{2}{*}{ Ethanol } & T. robustus & 3.93 & 8.72 & 3.80 & 2.41 & 2.66 \\
& L. squarrosulus & 5.86 & 15.04 & 8.54 & 5.16 & 4.71 \\
\multirow{2}{*}{ Control } & T. robustus & 3.39 & 5.24 & 3.93 & 8.48 & 1.94 \\
& L. squarrosulus & 4.35 & 5.74 & 4.57 & 3.04 & 4.03 \\
& - & 0.51 & 1.18 & 0.56 & 0.21 & 1.93 \\
\hline \hline
\end{tabular}

$\mathrm{FRAP}=$ ferric reducing antioxidant property; $\mathrm{TAP}=$ total antioxidant property.

Total antioxidant properties of the mushrooms extracts. The assay assessed the reducing power of the extracts based on their abilities to reduce Mo (VI) to Mo (V) and the results presented in Fig. 9a-c as gallic acid equivalent in $\mathrm{mg} / \mathrm{g}$.

Aqueous extracts exhibited higher reducing power than the methanol and ethanol extracts but all demonstrated concentration dependent increase in their reducing properties with positively strong correlations with corresponding TFC and TPC in the range TFC ( $\mathrm{r}=$ $0.915-0.983)$; TPC $(\mathrm{r}=0.953-0.995)$ for $T$. robustus and TFC ( $\mathrm{r}=0.795-0.993)$; TPC $(\mathrm{r}=0.855-0.999)$ for L. squarrosulus at 0.01-0.05 significant levels. Some of the extracts showed stronger reducing ability than

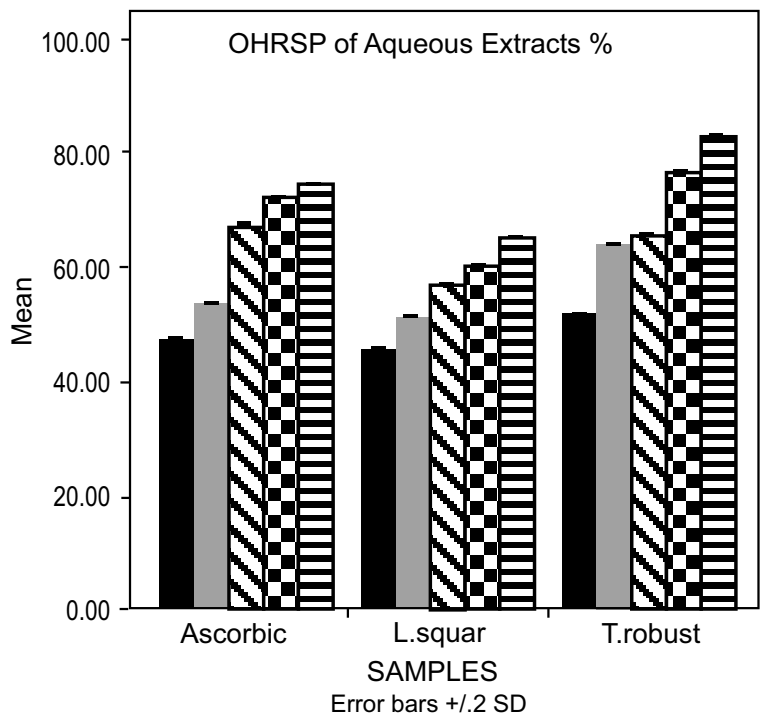

$1 \mathrm{mg} / \mathrm{mL} \square 2 \mathrm{mg} / \mathrm{mL} 3 \mathrm{mg} / \mathrm{mL}+4 \mathrm{mg} / \mathrm{mL}=5 \mathrm{mg} / \mathrm{mL}$

Fig. 6a. OH radical scavenging property in (Aq). gallic acid that was used as reference standard. The result of this study revealed that both mushrooms extracts generally showed effective $\mathrm{H}$ donor activity, reducing power and free radical scavenging activity. Supplementation of these mushrooms in food will serve as natural antioxidants and can be used as a remedy to fight with oxidative stress. Inhibitory action of extracts could be enhanced by full recovery of polyphenols using suitable solvents because the affinity of polyphenolic complex is not the same for all types of solvents used (Koffi et al., 2010). Factors that influence the extraction of phenolic compounds in plant materials include chemical nature, extraction method, sample size, time and storage conditions as well as the presence of interfering substances (Prior and Cao, 1999).

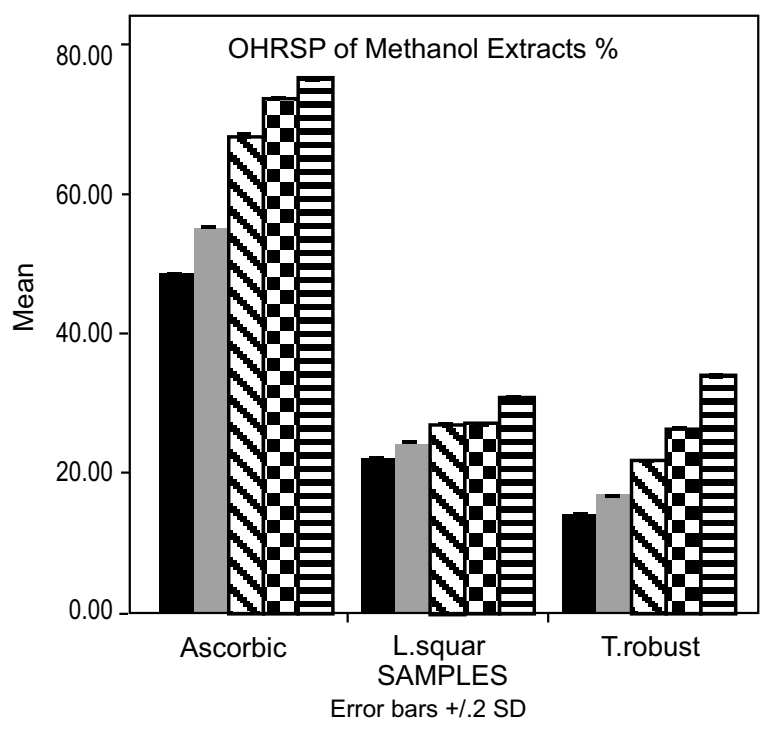

$1 \mathrm{mg} / \mathrm{mL} \square 2 \mathrm{mg} / \mathrm{mL} 3 \mathrm{mg} / \mathrm{mL} \boxminus 4 \mathrm{mg} / \mathrm{mL} \Xi 5 \mathrm{mg} / \mathrm{mL}$

Fig. 6b. $\mathrm{OH}$ radical scavenging property in (MEOH). 


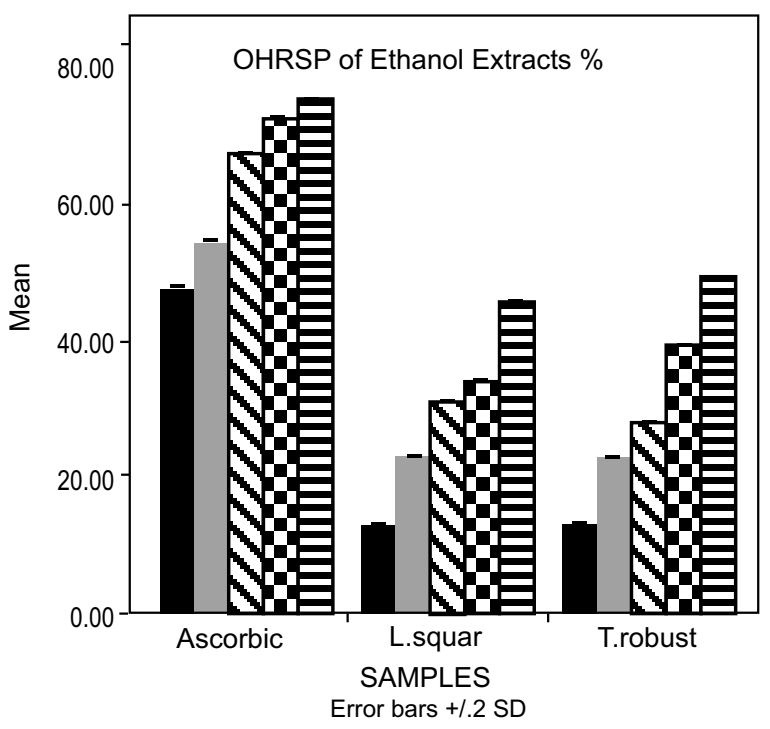

$1 \mathrm{mg} / \mathrm{mL} \square 2 \mathrm{mg} / \mathrm{mL}]^{3} \mathrm{mg} / \mathrm{mL} \square 4 \mathrm{mg} / \mathrm{mL}$ 国 $5 \mathrm{mg} / \mathrm{mL}$

Fig. 6c. OH radical scavenging property in (ETOH).

Antimicrobial activities of mushrooms. The antibacterial activities of aqueous and alcoholic extracts of the mushrooms at concentration $0.05 \mathrm{~g} / \mathrm{mL}$ are described in Fig. 10a. The ethanol extract of L. squarrosulus shows activity against $E$. coli; and the activity was fair as compared with streptomycin sulphate. Aqueous and methanol extracts of $L$. squarrosulus showed some inhibitory effect on S. typhii; and methanol extract was more effective and ethanol extract had no effect while

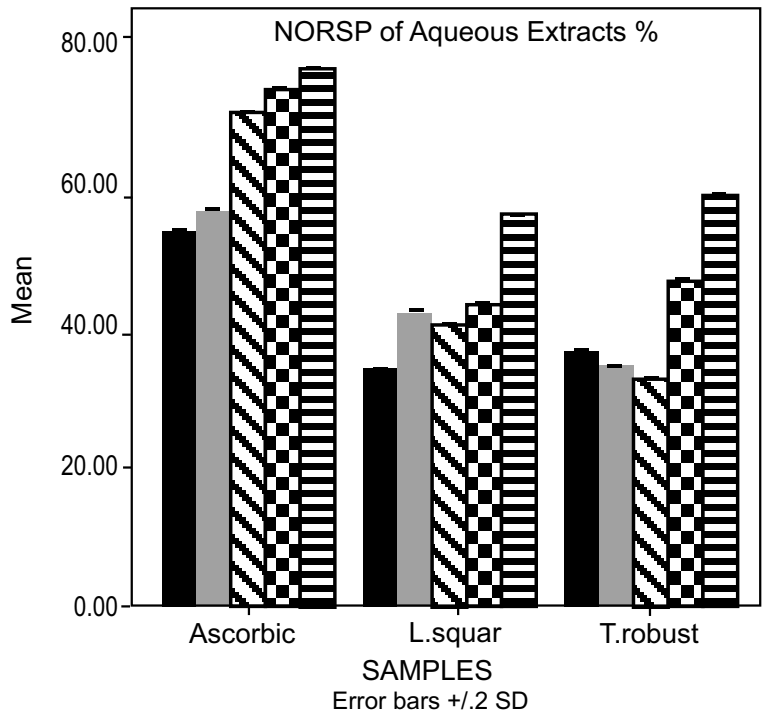

$1 \mathrm{mg} / \mathrm{mL} \square 2 \mathrm{mg} / \mathrm{mL} 3 \mathrm{mg} / \mathrm{mL} \square 4 \mathrm{mg} / \mathrm{mL} \boxminus 5 \mathrm{mg} / \mathrm{mL}$

Fig. 7a. NO radical scavenging property in (Aq). none of the extracts of $T$. robustus showed any activity against $S$. typhii and $E$. coli. This is at variance with the results obtained by Hamowia and salfat (1994) in their study. B. subtilis was susceptible to aqueous and ethanol extracts of $L$. squarrosulus as well as aqueous extract of T. robustus, L. squarrosulus extracts demonstrated well marked antimicrobial property than T. robustus and could be potential source of antimicrobial agent.

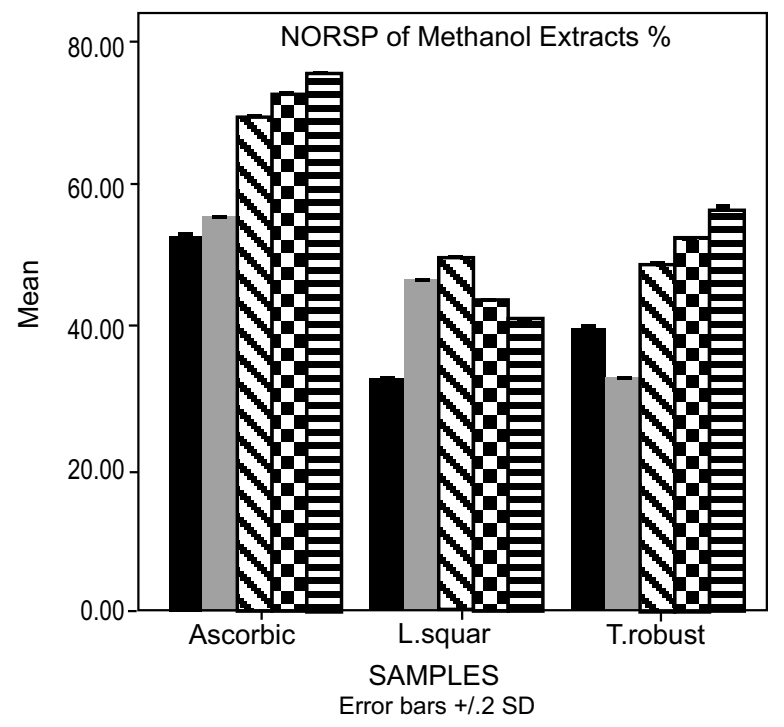

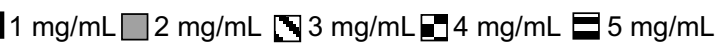

Fig. 7b. NO radical scavenging property in (MEOH).

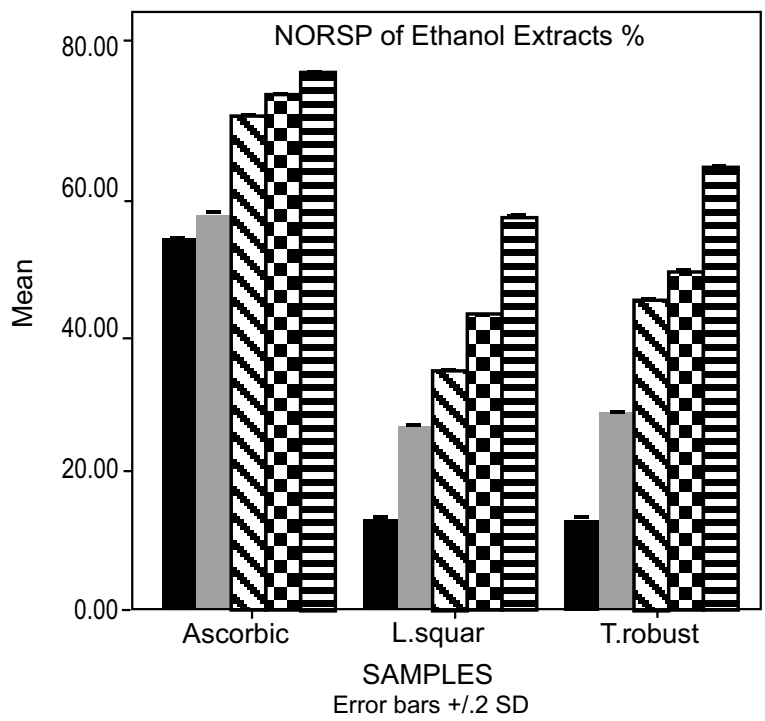

$1 \mathrm{mg} / \mathrm{mL} \square 2 \mathrm{mg} / \mathrm{mL} 3 \mathrm{mg} / \mathrm{mL} \mathbf{M g} / \mathrm{mL}$ 国 $5 \mathrm{mg} / \mathrm{mL}$

Fig. 7c. NO radical scavenging property in (ETOH). 
Only B. subtilis showed some susceptibility to T. robustus. A possible explanation for this is that gram negative organisms are resistant to extracts of T. robustus and may be due to the composition of their cell wall. The antifungal activities of the mushrooms extracts against the selected pathogens are presented in Fig. 10b. These present the percentage mycelia growth inhibition of the samples extracts against filamentous fungi, A. fumigatus,

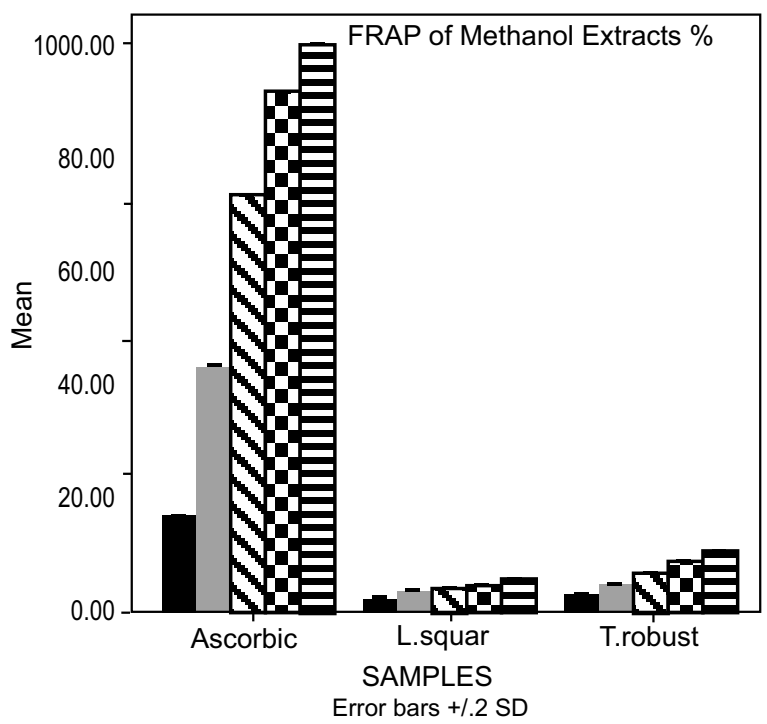

$1 \mathrm{mg} / \mathrm{mL} \square 2 \mathrm{mg} / \mathrm{mL} \$ 3 \mathrm{mg} / \mathrm{mL} \boxminus 4 \mathrm{mg} / \mathrm{mL} \boxminus 5 \mathrm{mg} / \mathrm{mL}$

Fig. 8a. Ferric reducing property in (Aq).

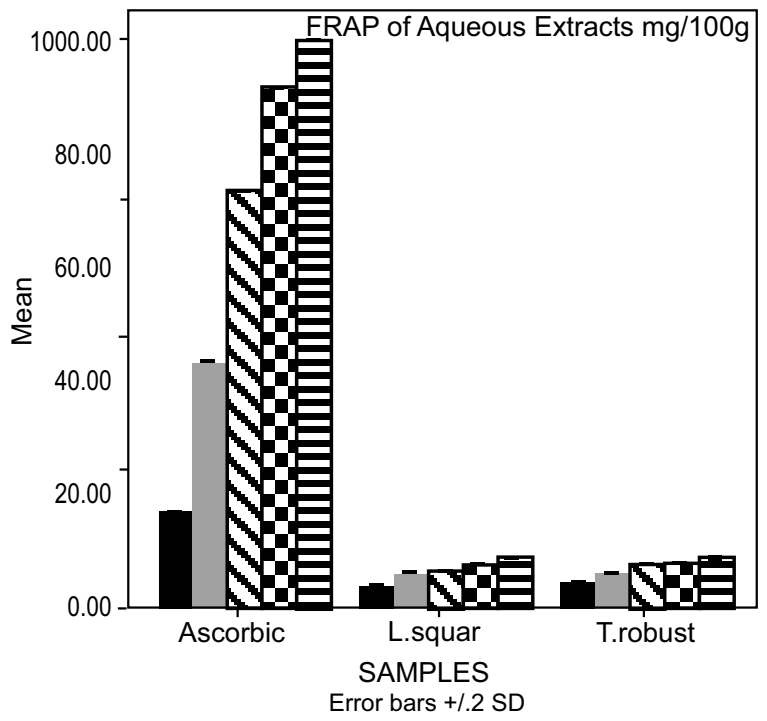

$1 \mathrm{mg} / \mathrm{mL} \square 2 \mathrm{mg} / \mathrm{mL} 3 \mathrm{mg} / \mathrm{mL} \square 4 \mathrm{mg} / \mathrm{mL} \boxminus 5 \mathrm{mg} / \mathrm{mL}$

Fig. 8b. Ferric reducing property in (MEOH).

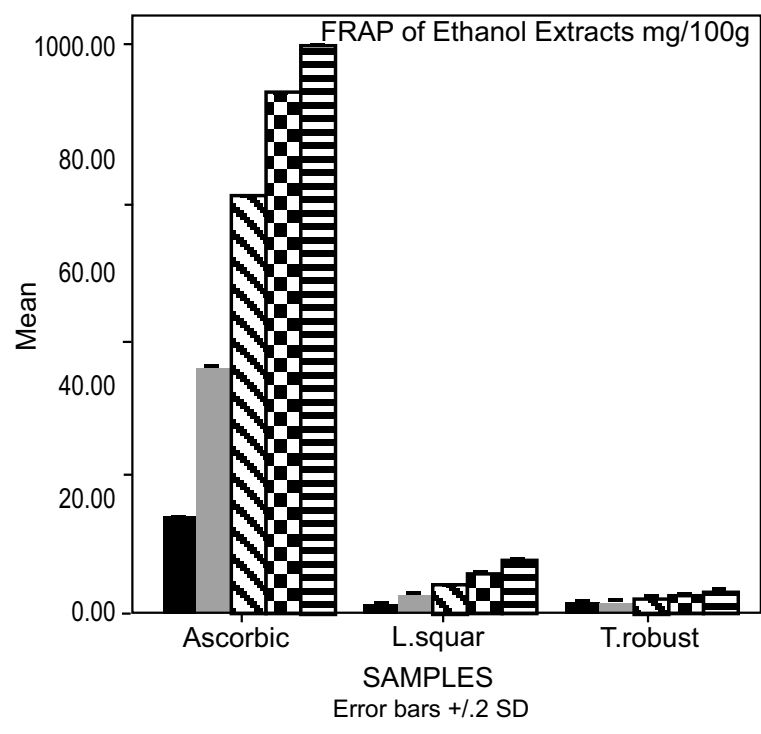

$1 \mathrm{mg} / \mathrm{mL} \square 2 \mathrm{mg} / \mathrm{mL} 3 \mathrm{mg} / \mathrm{mL} \mathbf{\square} \mathrm{mg} / \mathrm{mL}$ \# $5 \mathrm{mg} / \mathrm{mL}$

Fig. 8c. Ferric reducing property in $(\mathrm{ETOH})$.

F. solamii and C. albican. The results revealed that methanol extracts of both mushrooms were inactive against $A$. fumigatus, but the organism showed good susceptibility to aqueous and ethanol extracts. Aqueous, methanol and ethanol extracts of the two mushrooms showed strong inhibition against $F$. solarmi when compared with bonlate, which was used as positive control.

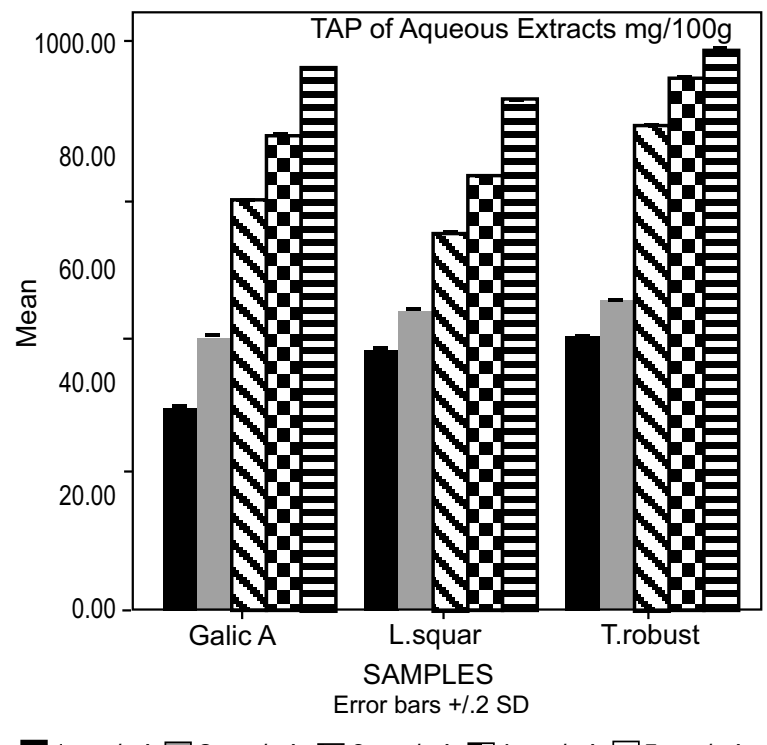

$1 \mathrm{mg} / \mathrm{mL} \square 2 \mathrm{mg} / \mathrm{mL} \quad 3 \mathrm{mg} / \mathrm{mL} \square 4 \mathrm{mg} / \mathrm{mL}$ 曰 $5 \mathrm{mg} / \mathrm{mL}$

Fig. 9a. Total antioxidant property in (Aq). 
While the aqueous extracts of the two mushrooms showed very weak activities against $C$. albican, the alcohol extracts demonstrated strong potency against the fungi. The high susceptibility displayed by the fungi to the extracts of the samples suggests that they contain bioactive agents that may be developed as antifungal drugs to treat infections caused by these organisms.

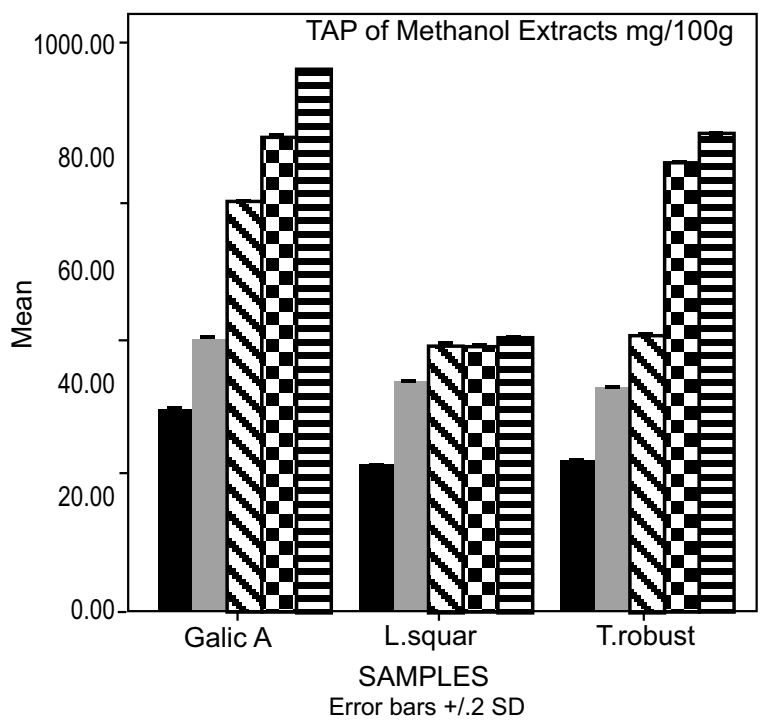

$1 \mathrm{mg} / \mathrm{mL} \square 2 \mathrm{mg} / \mathrm{mL} \mathbf{3 \mathrm { mg } / \mathrm { mL }} 4 \mathrm{mg} / \mathrm{mL} \equiv 5 \mathrm{mg} / \mathrm{mL}$

Fig. 9b. Total antioxidant property in (MEOH).

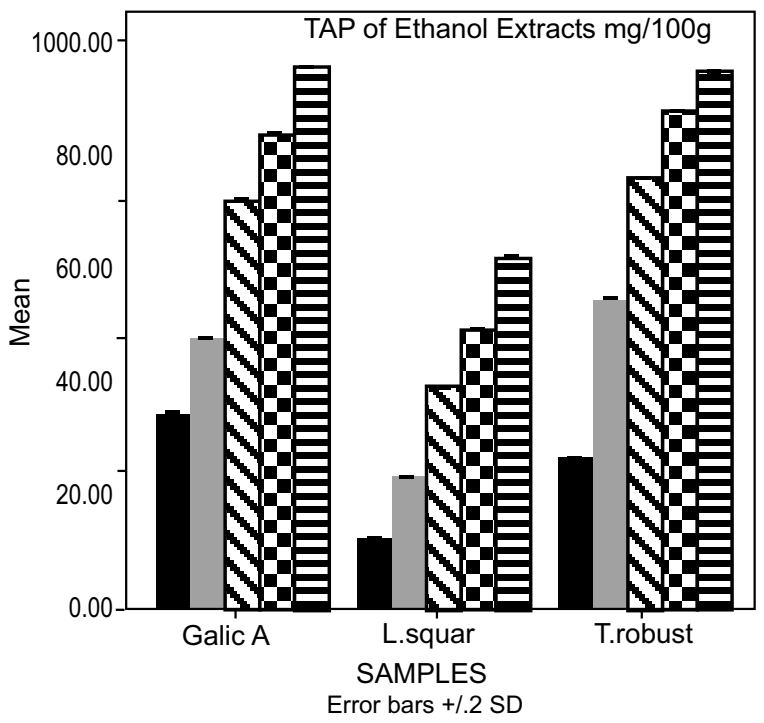

$1 \mathrm{mg} / \mathrm{mL} \square 2 \mathrm{mg} / \mathrm{mL} 3 \mathrm{mg} / \mathrm{mL} \square 4 \mathrm{mg} / \mathrm{mL}$ 표 $5 \mathrm{mg} / \mathrm{mL}$

Fig. 9c. Total antioxidant property in (ETOH).

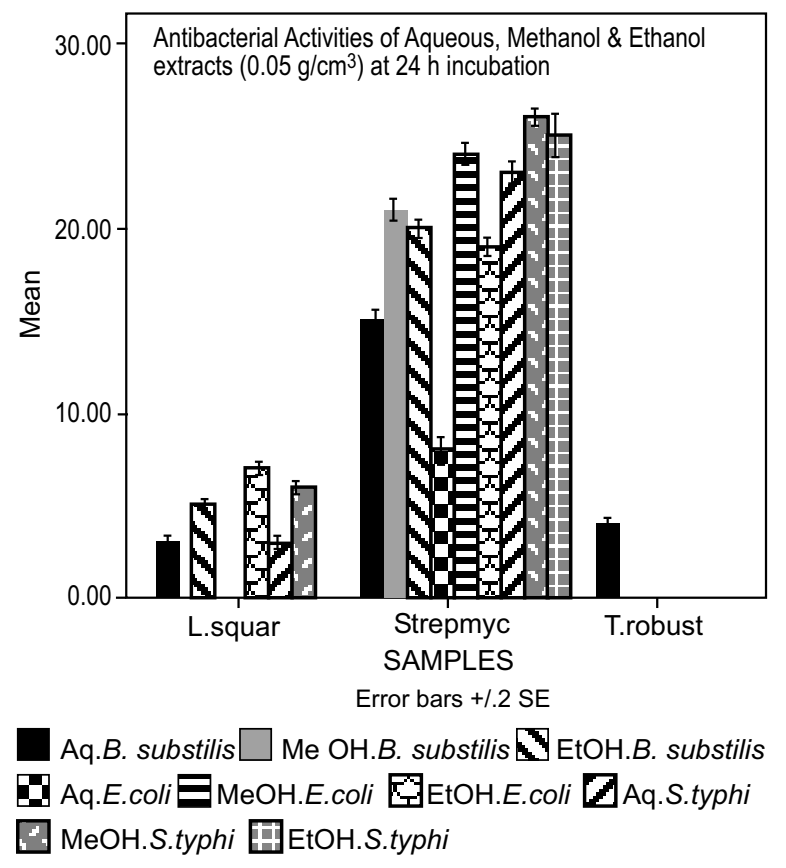

Fig. 10a. Total antioxidant property in (ETOH).

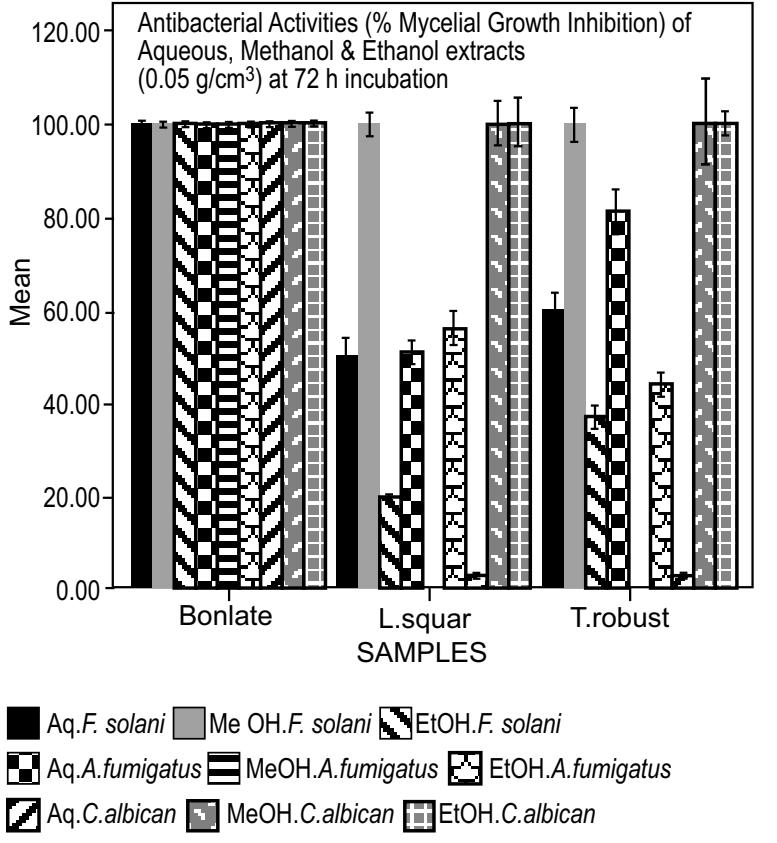

Fig. 10b. Antioxidant property of Mycelial growth.

\section{Conclussion}

T. robustus and L. squarrosulus possessed good antioxidant and antimicrobial properties in this study and a general strong and positive association was observed 
between antioxidant activities and total phenolic content as well as total flavonoids content. The inhibitory actions of extracts could be attributed to the presence of phytochemicals and phenolic compounds. Higher efficiency in recovery of polyphenols using suitable solvents will enhance the inhibitory actions. Thus the mushrooms can be potential natural sources of antioxidant and antibiotic agents. The results were positive at the laboratory level and further work can be carried out to find out the antioxidant strength of various phytochemicals using modern analytical methods and more antioxidant models and their effects in biological systems could be achieved.

\section{References}

Abdullah, N., Lau, C.C., Ismail, S.M. 2015. Potential use of Lentinus squarrosulus mushroom as fermenting agent and source of natural antioxidant additive in livestock feed. Journal of the Science of Food and Agriculture, 96: 1459-1466.

Alvarez-Parrilla, E., de-laRosa, L.A., Martínez, N.R., González, A.G.A. 2007. Total phenols and antioxidant activity of commercial and wild mushrooms from Chihuahua, Mexico. Ciencia Y. Tecnología Alimentaria, 5: 329-334.

Ames, B.M., Shigenaga, M.K., Hagen, T.M. 1993. Oxidants, antioxidants and the degenerative diseases of aging. In: Proceedings of the National Academy of Sciences, pp. 7915-7922.

Arbaayah, H.H., Umi, K.Y. 2013. Antioxidant properties in the oyster mushrooms (Pleurotus spp.) and split gill mushroom (Schizophyllum commune) ethanolic extracts. Mycosphere, 4: 661-673.

Aremu, M.O., Basu, S.K., Gyar, S.D., Goyal, A., Bhowmik, P.K., Datta, B. 2009. Proximate composition and functional properties of mushroom flours from Ganoderma spp., Omphalotus olearius (DC.) Sing. and Hebeloma mesophaeum (Pers.) Quél. used in Nasarawa State, Nigeria. Malaysian Journal of Nutrition, 15: 233-241.

Barros, L., Falcão, S., Baptista, P., Freire, C., VilasBoas, M., Ferreira, I.C.F.R. 2008. Antioxidant activity of Agaricus sp. mushrooms by chemical, biochemical and electrochemical assays. Food Chemistry, 111: 61-66.

Barros, L., Ferreira, M.J., Queirõs, B., Ferreira, I.C.F.R., Baptista, P. 2007. Total phenols, ascorbic acid, $\beta$ carotene and lycopene in Portuguese wild edible mushrooms and their antioxidant activities. Food Chemisty, 103: 413-419.

Colombo, M.L., Bosisio, E. 1996. Pharmacological activities of Chelidonium majus (Papaveraceae). Pharmacological Research, 33: 127-134.

Cook, N.C., Samman, S. 1996. Flavonoids-chemistry, metabolism, cardioprotective effects, and dietary sources. Nutritional Biochemistry, 7: 66-76.

Dharmendra, S., Manish, M., Monika, G., Poonam, S., Abhishek, G., Rajeev, N. 2012. Nitric oxide radical scavenging assay of bioactive compounds present in methanol extract of Centella asiatica. International Journal of Pharmacy and Pharmaceutical Science Research, 2: 42-44.

Duh, P.D., Tu, Y.Y., Yen, G.C. 1999. Antioxidant activity of aqueous extract of Hamjyur (Chrysanthemum morifolium Ramat). Lebensmittel-Wissenchaft \& Technologie, 32: 269-277.

Faweya, E.B., Ayeni, M.J., Kayode, J. 2015. Accumulation of natural radionuclides by some edible wild mushrooms in Ekiti State, Southwestern, Nigeria. World Journal of Nuclear Science and Technology, 5: 107-110.

Gulati, K., Ray, A., Masood, A., Vijayan, V.K. 2006. Involvement of nitric oxide (NO) in the regulation of stress susceptibility and adaptation in rats. Indian Journal of Experimental Biology, 44: 809-815.

Guno, S.C. 2009. Free radical scavenging activity of Aesculus indica leaves. International Journal of PharmTech Research, 1: 524-526.

Halliwell, B. 1996. Antioxidants in human health and disease. Annual Review of Nnutrition, 16: 33-50.

Hamowia, A.M., Salfat, A.M. 1994. Pharmacological studies on Vernonia amygdalina (Del) and Tithonia diversifolia (Gray). Journal of Veterinary Medicine, 42: 91-97.

Hearst, M., David, N., Graham, M., Linda, M., Ballard, B., Cherie, M., Sara, M., Stephen, M., John, E.M., Juluri, R.R. 2010. Antimicrobial properties of protein extracts from wild mushroom fungi and native plant species against hospital pathogens. Journal of Pharmacognosy and Phytotherapy, 2: 103-107.

Heo, K.S., Lim, K.T. 2004. Antioxidative effects of glycoprotein isolated from Solanum nigrum L. Journal of Medicinal Food, 7: 349-357.

IAEA, 1994. Intervention criteria in a nuclear or radiation emergency. International Atomic Energy Agency, 
Vienna, Safety Series No. 109.

Iwalokun, B.A., Usen, U.A., Otunba, A.A., Olukoya, D.K. 2007. Comparative phytochemical evaluation, antimicrobial and antioxidant properties of Pleurotus ostreatus. African Journal of Biotechnology, 6: 1732-1739.

Iweala, E.J., Okeke, C.U. 2005. Comparative study of the hypoglycemic and biochemical effects of Catharanthus roseus (Linn) G. apocynaceae (Madagascar periwinkle) and chlorpropamide (Diabenese) on alloxan-induced diabetic rats. Biokemistri, 17: 149-156.

Jagetia, G.C., Rao, S.K., Baliga, M.S., Babu, K.S. 2004. The evaluation of nitric oxide scavenging activity of certain herbal formulations in vitro: a preliminary study. Phytotherapy Research, 18: 561-565.

Jain, P.K., Himanshu, J. 2012. Coumarin: chemical and pharmacological profile. Journal of Applied Pharmaceutical Science, 2: 236-240.

Jayaprakasha, G.K., Mandadi, K.K., Shibu, M., Poulose, Y., Jadegoud, G.A., Nagana, G., Bhimanagouda, S. 2007. Inhibition of colon cancer cell growth and antioxidant activity of bioactive compounds from Poncirus trifoliata (L.) Raf. Bioorganic and Medicinal Chemistry, 15: 4923-4932.

Jonathan, S.G., Amos-Tautua B.M.W., Olawuyi O.J. 2011. Food values, heavy metal accumulation, aflatoxin contamination and detection of exopolysaccharrides in Lentinus Squarrosulus Berk, a Nigerian mushroom. African Journal of Agricultural Research, 6: 3007-3012.

Keleş, A., Koca, I., Gençcelep, H. 2011. Antioxidant properties of wild edible mushrooms. Journal of Food Process Technology, 2: 130-136.

Koffi, E., Sea, T., Dodehe, Y., Soro, S. 2010. Effect of solvent type on extraction of polyphenols from twenty three Ivorian plants. Journal of Animal and Plant Sciences, 5: 550-558.

Kosani, M.C, Rankovi, C.B., DaSi, C.M. 2013. Antioxidant and antimicrobial properties of mushrooms. Bulgarian Journal of Agricultural Science, 19: 1040-1046.

McCutcheon, A.R., Ellis, S.M., Hancock, R.E.W., Tower, G.H.N. 1994. Antifungal screening of medicinal plants of British Columbian native people. Journal of Ethnopharmacology, 44: 157-169.

Nedelkoska, D.N., Nataija, A.P., Haris, A., Dafina, V., Emiija, I., Mitko, K., DzokoKungulovsk, I. 2013.
Screening of antibacterial and antifungal activities of selected macedonian wild mushrooms. Journal of Natural Science, 124: 333-340.

Obodai, M., Ferreira, I.C.F.R., Fernandes, Â., Barros, L., Mensah, D.L.N., Dzomeku, M., Urben, A.F., Prempeh, J., Takli, R.K. 2014. Evaluation of the chemical and antioxidant properties of wild and cultivated mushrooms of Ghana. Molecules, 19: 19532-19548.

Prieto, P., Pineda, M., Aguilar, M. 1999. Spectrophotometric quantitation of antioxidant capacity through the formation of phosphomolybdenum complex: pecific application to the determination of vitamin E. Analytical Biochemistry, 269: 337-341.

Prior, R.L., Cao, G. 1999. Variability in dietary antioxidant related natural product supplements: the need for methods of standardization. Journal of American Nutraceutical Association, 2: 46-56.

Priya, L.J., Srinivasan, V. 2013. Studies on the antibacterial activities of mushroom. International Journal of Current Microbiology and Applied Sciences, 2: 184-189.

Pulido, R., Bravo, L., Saura-Calixto, F. 2000. Antioxidant activity of dietary polyphenols as determined by a modified ferric reducing/antioxidant power assay. Journal of Agricultural and Food Chemistry, 48: 3396-3402.

Rajan, S., Mahalakshmi, S., Deepa, V.M., Sathya, K., Shajitha, S., Thirunalasundari, T. 2011. Antioxidant potentials of Punica granatum fruit rind extracts. International Journal of Pharmacy and Pharmaceutical Science, 3: 82-88.

Rao, J.R., Smyth, T.J., Millar, B.C., Moore, J.E. 2009. Antimicrobial properties of shiitake mushrooms (Lentinula edodes). International Journal of Antimicrobial Agents, 33: 591-592.

Rice-Evans, C.A., Miller, N.J., Paganga, G. 1997. Antioxidant properties of phenolic compounds. Trends in Plant Science, 2: 152-159.

Silva, A.R.H., Moreira, L.R., Brum, E.S., Freitas, M.L., Boligon, A.A., Margareth, L.A., Roman, S.S., Mazzanti, C.M., Brandão, R. 2014. Biochemical and hematological effects of acute and sub-acute administration to ethyl acetate fraction from the stem bark Scutia buxifolia Reissek in mice. Journal of Ethnopharmacology, 153: 908-916.

Singleton, V.L., Orthofer, R., Lamuela-Raventos, R.M. 1999. Analysis of total phenols and other oxidation 
substrates and antioxidants by means of FolinCiocalteu reagent. Methods in Enzymology, 299: 152-178.

Srinivasan, D., Nathan, S., Suresh, T., Perumalsamy, P.L. 2001. Antimicrobial activity of certain Indian medicinal plants used in folkloric medicine. Journal of Ethnopharmacology, 74: 217-220.

Umamaheswari, M., Chatterjee, T. K. 2000. In vitro antioxidant activities of the fractions of Coccinia grandis L. leaf extract. African Journal of Traditional, Complementary and Alternative Medicine, 5: 61-73.

Ursini, F., Maiorino, M., Morazzoni, P., Roveri, A., Pifferi, G. 1994. A novel antioxidant flavonoid (idb 1031) affecting molecular mechanisms of cellular activation. Free Radical Biology and Medicine, 16: 547-553.

Yamac, M., Bilgili, F. 2006. Antimicrobial activities of fruit bodies and/or mycelial cultures of some mushroom isolates. Pharmaceutical Biology, 44: 660-667.

Yun-Zhong, F., Sheng, Y., Guoyao, W. 2002. Free radicals, antioxidants, and nutrition. Nutrition, 18: 872-879.

Zhishen, J., Mengcheng, T., Wu, J. 1999. The Determination of flavonoid contents in mulberry and their scanvenging effects on superoxide radicals. Food Chemistry, 64: 555-559. 